Russian State University for the Humanities / International Centre of Anthropology of the National Research University Higher School of Economics, Moscow; aldavletshin@mail.ru

\title{
Laryngealized vowels and laryngealized consonants in the history of the Totonacan languages of Mexico
}

The paper argues that Papantla Totonac has lost the original contrast between modal and laryngealized vowels after sonorants and thus developed a system of plain and glottalized stops, affricates and sibilants from the original system of modal and laryngealized vowels. Similarly, Misantla Totonac lost the contrast between modal and laryngealized vowels after sibilants, which resulted in a system of plain and glottalized stops, affricates and sonorants. These sound changes can be explained as being due to different mechanisms of glottalization regarding three classes of consonants - stops, sonorants and sibilants. Apapantilla Totonac and Zapotitlán de Méndez Totonac remain conservative in their treatment of the original Proto-Totonacan laryngealized vowels.

Keywords: Tepehua-Totonacan languages; Totonac language; laryngealized vowels; creaky voice; glottalized consonants; ejective consonants; laryngealized consonants; glottalized sibilants; glottalized sonorants.

The Tepehua-Totonacan linguistic family consists of a dozen of closely related languages spoken by approximately 290,000 people in the states of Veracruz, Puebla, and Hidalgo of Mexico. The exact number of the languages is unknown; some of them are spoken in one town and most of them show considerable dialectal variations (García Rojas 1978, MacKay 1994a, Levy \& Beck 2012). These languages are divided in two branches - Tepehua and Totonacan, hence the name I use for the family. Until recently, these languages have been considered as dialects of Totonac and Tepehua, probably because the languages of the family are extremely conservative from the phonological point of view. According to lexicostatistical estimations, Tepehua and Totonac separated from each other around 3000 B.P. The Totonacan branch split off around 2000 B.P. when Misantla Totonac separated from the other Totonac languages (Figure 1).

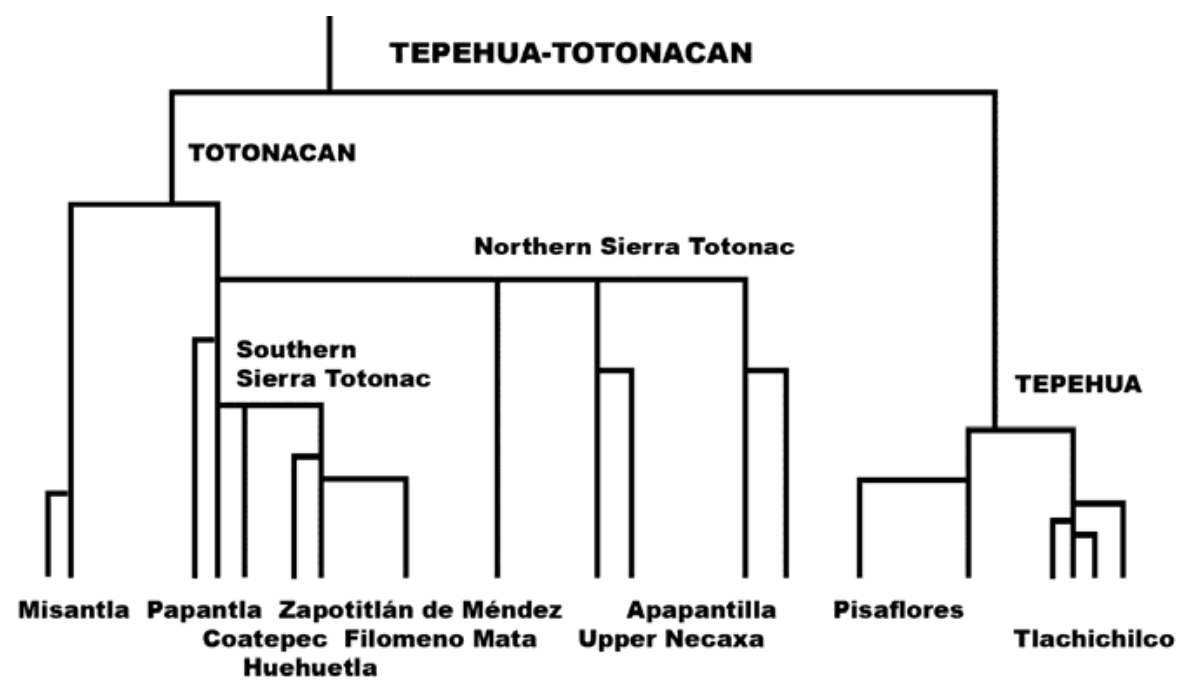

Figure 1. Classification of the Tepehua-Totonacan languages 
Speakers of Tepehua-Totonacan languages quite often do not have names for their languages and use the names totonaco and tepehua. These are derived from Aztec ethnonyms tepe:wa? 'highlanders' (literally 'owners of mountains') and toto:naka? 'people of the hot land' (literally 'ones of the place where it heats'). Specific designations for different languages come from the names of the principal towns where they are spoken, which is a common practice in Mesoamerican linguistics.

The basic phonological opposition in most of the Totonacan languages is the contrast between modal and laryngealized (creaky voice) vowels, while the Tepehua languages systematically contrast plain and glottalized stops and affricates. Importantly, glottalized consonants of the Tepehua languages correspond to laryngealized vowels of the Totonacan languages (Arana 1963: 124). Since there are relatively few languages in the world in which creaky voice has a phonemic status, the development of laryngealized vowels is interesting from a typological point of view. The family is also of particular interest for the laryngeal theory of ProtoIndo-European, because in at least one language of the family, Olintla Totonac, historically laryngealized vowels have developed new vocalic qualities (for data on Olintla Totonac, see Tino 2020). During the last decade, the reconstruction of Proto-Tepehua-Totonacan has become a subject for heated debates: no fewer than three different Proto-Tepehua-Totonacan inventories have been proposed - one consisting of modal and laryngealized vowels (Arana 1963, Brown, Beck et al. 2011, Watters 2018), one of glottalized stops and affricates (MacKay \& Trechsel 2018a,b), and one more of glottalized stops, affricates and sonorants (Davletshin 2019).

I have an impression both from publications and informal talks that many fellow totonacanists tend to consider laryngealization as a highly unstable feature in the history of the Totonacan languages and easily assume irregular sound changes involving laryngealized vowels (e.g. MacKay \& Trechsel 2018a,b). The author consents to the former statement but disagrees with the last one. In a recent paper, I have argued that the correspondences involving word-final laryngealized vowels in nominals in the Totonacan languages are numerous and complex but highly regular and phonologically motivated (Davletshin 2018). The aim of the present paper is to show that phonological systems of two Totonacan languages, which have been traditionally described as contrasting modal and laryngealized vowels, can be analysed as systems that contrast plain and glottalized consonants.

I will start with works in which the term "laryngealized vowel" was originally introduced by Hermann Aschmann and Kenneth Pike (in their phonological description of Zapotitlán de Méndez Totonac) and recapitulate their arguments. Then, I will show that this kind of analysis is not relevant in the case of Papantla Totonac, which should be rather described as a language with plain and glottalized stops, affricates and sibilants. I will proceed with Misantla Totonac and argue that the language can be alternatively described as one contrasting plain and glottalized stops, affricates and sonorants. Finally, I will try to show that both languages are innovative in respect to glottalized consonants and that Proto-Totonacan was a language that had both modal and laryngealized vowels.

\section{Laryngealized vowels in Totonacan languages}

Across the Totonacan language family, both the description and phonetic realization of the laryngealization feature significantly vary. Rafael Alarcón Montero (2008: 94-96) and Ester Herrera Zendejas (2009: 42-44) describe three forms of non-modal vowels in Papantla Totonac: 1) creaky voice throughout the entire duration of the vowel, characterized by irregular glottal pulses, 2) creaky voice for only a portion of the vowel, typically the beginning, and 3) stiff 
voice, indicating a more subtle degree of laryngealization. Specific peculiarities of laryngealization depend on the context. In Papantla Totonac, laryngealized vowels often involve voicing of preceding stops (Herrera Zendejas 2009: 45). In many varieties, laryngealized vowels are followed by strong glottal stops in phrase-final position; in this position non-modal quality of the vowel is easily perceived (for example, in San Francisco Totonac, based on author's fieldwork data of 2007).

In many varieties, some speakers seem to laryngealize more clearly and reliably than others. Older speakers have hoarser voices because of well-known underlying physiological reasons and thus tend to overlaryngealize. On the contrary, children and teenagers tend to underlaryngealize, which might be due to the acquisition of laryngealization at a late age. Both sex and age variation in the realization of laryngealized vowels are interesting subjects for future studies. Many researchers, the author among them, have difficulties in identifying Totonacan laryngealized vowels by ear. I tend to hear clearly the laryngealized vowels following stops and affricates, possibly, because (phonetically) laryngealized vowels are restricted to these positions in the language of my primary fieldwork, which is Pisaflores Tepehua. Interestingly enough, even linguistically trained native speakers of Totonacan languages often have difficulties in identifying laryngealized vowels, for example, in writing.

Glottal stops are prominent in many Tepehua-Totonacan languages; these come from different sources and sometimes have different realizations. At the same time, the phonemic status of the glottal stop in Totonacan languages is not always clear; some researchers include it in the phonological inventory while others do not. Glottal stops are often accompanied by automatic laryngealization of the following vowel. The last but not the least important observation is that glottal stops, glottalized consonants and laryngealized vowels all involve articulatory movement of the glottis constriction. From this point of view, the widely established terms are misleading. The terms "glottalized consonants" and "glottalized vowels" might be more representative of the articulatory similarities between the corresponding sounds. One can say that the Tepehua and Totonac branches of the Totonacan family tree are differentiated in the temporal location of laryngealization in the syllable: Tepehua languages feature laryngealization in syllable onsets, while Totonac languages restrict it to the syllable nucleus (Arana 1963: 124).

However, the main subject of the present paper is not the phonetics of laryngealized vowels but their phonology - in other words, our main concern here are distributions and restrictions.

\section{Zapotitlán de Méndez Totonac}

Zapotitlán de Méndez Totonac was the first extensively documented language of the family; it boasts a republished dictionary and number of papers on various grammatical topics (Herman Aschmann 1946, 1962, 1983, etc., Elizabeth Aschmann 1984, Aschmann \& Wonderly 1952). Herman Aschmann calls the language Highland Totonac (in Spanish, totonaco, dialecto de la Sierra).

It is no wonder that laryngealized vowels were first noticed and described during the study of this language, although glottal stops in word-final position had already been found by Landis Christiansen in a variety of Sierra Totonac (Christiansen 1937: 152). ${ }^{1}$

The phonological system of Zapotitlán de Méndez Totonac can be presented in the following way in the International Phonetic Alphabet (IPA). Correspondingly, a subscripted tilde

\footnotetext{
${ }^{1}$ The exact location of Ladis Christansen's fieldwork is unknown. He indicates that there are three dialects of Totonaco -Totonaco of the Coast, Totonaco of Papantla and Totonaco of Sierra - and specifies that his study is limited to the Totonaco of Sierra (Christansen 1937: 52).
} 
under the vowel $(\underline{V})$ is used to indicate laryngealization. In works by Herman Aschmann and co-authors, laryngealized vowels are indicated by means of an apostrophe ( $\left.\mathrm{V}^{\prime}\right)$ or a superscript symbol of glottal stop above the vowel $\left(V^{3}\right)$. The system is not described explicitly in the paper on the phonology of the language but can be easily deduced from it (Aschmann 1946).

\begin{tabular}{|c|c|c|c|c|c|c|}
\hline \multicolumn{7}{|c|}{ Consonants } \\
\hline $\mathrm{p}$ & $\mathrm{t}$ & & & $\mathrm{k}$ & $\mathrm{q}$ & \\
\hline & $\mathrm{ts}$ & $\mathrm{t}$ & $\mathrm{t}+$ & & & \\
\hline & $\mathrm{s}$ & $\int$ & $\mathrm{t}$ & & & $\mathrm{h}$ \\
\hline $\mathrm{m}$ & $\mathrm{n}$ & & & & & \\
\hline & & & $\mathrm{l}$ & & & \\
\hline $\mathrm{w}$ & & $\mathrm{y}$ & & & & \\
\hline
\end{tabular}

\begin{tabular}{|c|c|c|}
\hline \multicolumn{3}{|c|}{ Vowels } \\
\hline i, i: & & u, u: \\
i, i: & & u, u.: \\
\hline & a, a: & \\
& a, a: & \\
\hline
\end{tabular}

We can see that the vocalic system consists of twelve phonemes where three vocalic qualities are combined with two degrees of vowel lengths and laryngealization or its absence. Five vocalic qualities are found on surface but mid vowels [e] and [o] are allophones of high vowels /i/ and /u/ in the context of uvular stops. Herman Aschmann (1946: 35-36) describes three different types of laryngealized vowels: 1) a modal vowel followed by a glottal stop, 2) a vowel followed by glottal stop but also affected by this glottal stop so as to be accompanied by a more or less rough glottal vibration, laryngealization or glottalization, and 3) vowel preceded and followed by a glottal stop with complete laryngealization of the vowel. These types depend on the nature of the preceding consonants. When the laryngealized vowel is preceded by a voiceless consonant, the first type occurs, or a mild form of the second type with only slight laryngealization at the end. When the laryngealized vowel is preceded by a sonorant, it may be completely laryngealized and the preceding sonorant on its off-glide is slightly assimilated to the laryngealized quality of the vowel. When the laryngealized vowel is preceded by another laryngealized vowel, the second one undergoes complete laryngealization as well. When two laryngealized vowels are separated by a sonorant, the second vowel is fully laryngealized and the medial sonorant also undergoes slight laryngealization. When the laryngealized vowel occurs in phrase-initial position, an initial glottal stop occurs, and the vowel is completely laryngealized. This word-initial glottal stop disappears in normal speech when a preceding consonant-final word is added. Importantly, modal vowels are banned in the initial position of lexical roots and prefixes.

Herman Aschmann (1946: 41) and Kenneth Pike (Pike 1947: 148) offer the following analysis. Both scholars deal with the same set of data and their descriptions seem to have resulted from shared conversations. They treat the phonetic glottal stop as part of a vowel nucleus, rather than a separate consonant because of the distribution of glottal stop (or laryngealization). The glottal stop can be treated as a separate consonant on a par with stops, affricates, nasals and so on, but one which differs widely from them in its distributional characteristics. Such an analysis would allow us to reduce the number of vocalic phonemes from twelve to six. However, distributional differences between the glottal stop and the other consonants are so striking that, according to the authors, the system of modal and laryngealized vowels seems to better reflect the structure of the language. The distributional evidence is as follows.

First, the glottal stop is used with much greater frequency than any single consonant. According to Herman Aschmann (1946: 41), in a sample text containing 1834 syllables, 732 contained a glottal stop. 
Second, the glottal stop, as a consonant, would nearly double the number of consonant clusters, since it can occur before any word-medial or word-final single consonant or cluster. Furthermore, the distribution of $/ \mathrm{p} /, / \mathrm{t} /, / \mathrm{q} /, / \mathrm{y} /, / \mathrm{w} /, / \mathrm{m} /$ and $/ \mathrm{n} /$ would seem odd, in that, word-finally, they would appear only after a vowel or as part of a cluster with a preceding [2]; stating that in word-final position they occur after either laryngealized or non-laryngealized nuclei would be less controversial.

Third, laryngealized vowels are found in Spanish loans where they are substituted for non-laryngealized ones: a:nima:t 'beast' (Spanish animal), wi:lah 'personal name' (Spanish, Manuela), kwi:rsah 'by necessity' (Spanish, fuerza)².

Fourth, when there are alternate forms of a morpheme, and the particular usage is determined by whether or not the preceding morpheme ends in a consonant or a vowel, forms with final phonetic glottal stops are treated the same way as morphemes ending in modal vowels. For example, the suffix 'second person object' -ni loses its vowel after non-laryngealized (a) and laryngealized nuclei (b) but not after a regular consonant (c): Jkan 'it bit you' (a), tfin 'he tied you' (b) and nikni 'he hit you' (c). Aschmann (1946: 41) translates tfin as 'he tied it', but this translation is mistaken (see also Pike 1947: 148). Similarly, morpheme-initial /y/ is retained after non-laryngealized and laryngealized vowels but not after regular consonants: fkaya:w 'we bite it', tfiya:w 'we tied it', nika:w 'we hit it'.

Fifth, in certain syntactic positions in the phrase syntactic juncture lengthens word-final vowels (a), but not vowels followed by a consonant (c); laryngealized vowels are lengthened, ignoring the presence of the phonetic stop (c).

\begin{tabular}{|c|c|}
\hline snapapa fu:wa & snapapa: furwa (a) \\
\hline 'the white fur' & 'the fur is white' \\
\hline qama li:wat & qama: li:wat (c) \\
\hline 'tasty food' & 'the food is tasty' \\
\hline tkitit skuhni & tkitit skuhni (c) \\
\hline 'a lazy worker' & 'the worker is lazy' \\
\hline
\end{tabular}

Sixth, in certain situations, a morphological process involves the substitution of a laryngealized vowel for a non-laryngealized one; treating the glottal stop as a regular consonant implies that the glottal stop here is technically an infix, which is not very convenient in view of other characteristics of the language as a whole; compare lismaniya:w 'we (incl.) accustom ourselves to it' with lismaniya:tit 'you (pl.) accustom yourselves to it'. Importantly, the second person subject form involves laryngealization of each of the vowels which are preceded by a voiced continuant.

Seventh, laryngealized vowels in medial position are somewhat unstable. There are no cases of deletion of medial consonants which would parallel the assumed deletion of the phonetic glottal stop, represented on the surface by the phonemic substitution of non-laryngealized for laryngealized nuclei: [wanif] or [wanif] 'he said it' and [lawa] or [lawa] 'you did it'.

Herman Aschmann also notices significant dialectal differences in the realization of laryngealized vowels and considers this fact as an argument in favour of his analysis. According to him (Aschmann 1946: 42), in certain words where a phonetic glottal stop follows the vowel in Zapotitlán de Méndez that same word is pronounced in Coyutla with a glottal stop preceding

2 Stress is not marked in works on Zapotitlán de Méndez Totonac, nor are stress assignment rules stated explicitly. There is a big deal of variation in stress assignment in Totonacan languages (see MacKay 2011), and I make no attempts to "reconstruct" stress in Zapotitlán de Méndez Totonac. 
the vowel, and in Concepción it is realized as laryngealization of a vowel without any glottal

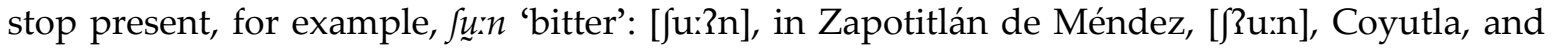
[ ư:n], Concepción).

We can see that for both Aschmann and Pike the decisive argument in favour of a system with modal and laryngealized vowels is the distribution of the phonetic glottal stop in relation to its adjacent vowels and consonants. We can also see that the offered analysis is inextricably linked to the Totonac variety under study: the distribution of laryngealization is analysed in relation to following consonants rather than preceding ones. We may assume that if the main subject of the study were Coyutla Totonac, the distribution of laryngealization in relation to the preceding consonants might have been likely considered as well, since this is where the phonetic glottal stop is heard in Coyutla Totonac.

It is worth mentioning that the seven distributional criteria presented by Aschmann and Pike do not contradict the idea of a system of phonologically significant glottalized consonants preceding phonetically laryngealized vowels. Such an idea requires us to assume (1) some morphophonetic alternations between glottalized and plain consonants and (2) a rule according to which glottalized consonants become deglottalized in syllable-final position. Both phenomena are quite common in languages with plain and glottalized consonants (Fallon 2002) and also found in Pisaflores Tepehua, for example (Davletshin 2016). It is important to emphasize here that to suggest an alternative description is not necessarily about being right or wrong. It is quite normal for the same language to be adaptable for different models of description, and importantly, with each of the suggested models having its advantages and disadvantages depending on different objectives and perspectives of research.

Interestingly enough, the distribution of laryngealized vowels in Spanish loans given by Aschmann depends on the preceding consonant - laryngealized vowels are found after sonorants and word-initially, while modal vowels are found after voiceless consonants: a:nima:t 'beast' (Spanish animal), wi:lah 'personal name' (Spanish, Manuela), kwirssah 'by necessity' (Spanish, fuerza), kapih 'coffee' (Spanish, kafé) fa:patuh 'Saturday' (Spanish, sabado), pisintih 'personal name' (Spanish, Vicente) ${ }^{3}$. The only exception to this rule is the second syllable of the name wi:lah, where the vowel after the sonorant is followed by a glottal fricative. Modal vowels are banned word-initially in Zapotitlán de Méndez Totonac. I do not have a good explanation why either Spanish or Nahuatl sonorants should be borrowed as glottalized consonants into Totonacan languages. One theoretical explanation is that, since glottalized sonorants are rare in the language, they might be perceived as special markers of loanwords. However, I am not aware of other typological examples when loanwords are marked by phonemes absent in the donor language. A few Spanish loans show non-modal vowels following sonorants in the published dictionary: kila:ntu 'coriander (Spanish, cilantro)', li:mu:nif 'lime (fruit and tree, Spanish, lemón)', fti:la:n 'chicken (Spanish, castilla)', etc. They might represent a later stratum of borrowings or, alternatively, borrowings via Nahuatl, which played the role of lingua franca in the Early Colonial period.

Importantly, in Zapotitlán de Méndez Totonac laryngealized vowels are not attested following the glottal fricative $/ \mathrm{h} /$; when this phoneme is followed by a vowel in the same word, it is realized as a voiceless velar fricative [x] (Aschmann 1946: 36-37). This gap in the distribution of laryngealized vowels has been never commented upon in published literature. The only counterexample to the stated observation found in a published dictionary (Aschmann 1983) is the word tihi 'road' where the laryngealized vowel is found word-finally.

${ }^{3}$ According to Aschmann (1946: 41): "In adapting Spanish loans to the phonemic system of Totonaco, laryngealized vowels are sometimes (although nonpredictably) substituted for the non-laryngealized types of Spanish”. 
At least one second person subject form shows laryngealization after a glottal fricative: tyha 'you (sg.) spit', cf. tfuh- 'to spit' (Aschmann \& Wonderly 1952: 139). Here laryngealization marks the second person subject. Laryngealized vowels in word- and phrase-final position are realized in a particular way, with a strong glottal stop, in many Totonacan varieties (see Coatepec Totonac in McQuown 1990 and Filomeno Mata Totonac in McFarland 2009). It is probable that word-final laryngealized vowels historically arise from a nominalizer *-? (Davletshin 2018). In other words, word-final laryngealized vowels can be phonologized as underlying modal vowels followed by a glottal stop. The ban on the glottal stop / / after a glottal fricative $/ \mathrm{h} /$ is easy to explain because both consonants share the same place, but different manners of articulation. The ban on laryngealized vowels following glottal fricatives can be seen from the following table, which shows statistical correlations between laryngealized and non-laryngealized vowels in initial syllables of the lexical entries found in the published dictionary (Aschmann 1983).

\begin{tabular}{|c|c|c|c|c|c|c|c|c|c|c|c|}
\hline & $\mathrm{p}_{-}$ & $t_{-}$ & $\mathrm{k}_{-}$ & $\mathrm{q}_{-}$ & - & & & & $\mathrm{ts}_{-}$ & $t_{-}$ & $\mathrm{tt}_{-}$ \\
\hline${ }_{-} \mathrm{V}$ & 189 & 201 & 81 & 87 & $!^{*}$ & & & $-\mathrm{V}$ & 33 & 28 & 13 \\
\hline _V & 46 & 38 & 61 & 39 & 182 & & & -V V & 42 & 48 & 11 \\
\hline & $\mathrm{s}_{-}$ & $\int_{-}$ & $t_{-}$ & $h_{-}$ & & & $\mathrm{m}_{-}$ & $\mathrm{n}_{-}$ & $1_{-}$ & $\overline{\mathrm{w}_{-}}$ & $\overline{y_{-}}$ \\
\hline${ }_{-} \mathrm{V}$ & 34 & 30 & 8 & 20 & & _V & 175 & 12 & 222 & 11 & 3 \\
\hline$-V$ & 10 & 14 & 3 & $!^{*}$ & & _V & 28 & 6 & 12 & 19 & 5 \\
\hline
\end{tabular}

These statistics are somewhat misleading because some entries in the dictionary contain identical roots and, more importantly, the language employs a number of highly productive derivational prefixes. Nevertheless, the table clearly shows that there is a ban on laryngealized vowels following glottal fricatives and another one on word-initial modal vowels.

It is important to mention that laryngealized vowels carry low lexical load in Zapotitlán de Méndez Totonac, apart from examples where laryngealization distinguishes second person subject verbal forms from third person subject verbal forms. Here are all the minimal pairs found in published works (Aschmann 1983: 141, 143).

$\begin{array}{ll}\text { tkaka 'ashes' } & \text { tkaka 'spicy' } \\ \text { Jkuta 'sour' } & \text { Jkuta 's/he unties X' } \\ \text { Jlakan 'theirs' } & \text { Jlakan 'his face' } \\ \text { Jqątni 'his blood' } & \text { Jqatni 'its opening' } \\ \text { stapu 'biting midge (Spanish, jején)' } & \text { stapu 'beans' }\end{array}$

Laryngealization marking second person subject forms results in many minimal pairs, since imperfective forms for second person singular and third person singular coincide in their surface realization if the verb stem ends in a non-sonorant. Here is an example from the paper where this phenomenon was first discussed (Nida 1949: 63, see also Aschmann \& Wonderly 1952: 139):

$$
\text { pafa cyou (sing.) bathe' pafa 's/he bathes' }
$$

It is particularly instructive to compare Zapotitlán de Méndez Totonac with Pisaflores Tepehua. In Pisaflores Tepehua phonologically glottalized consonants may be superficially realized in different ways (author's fieldwork from 2011). Syllable-initially, glottalized bilabial and dental stops $/ \mathrm{p}^{\prime} /$ and $/ \mathrm{t}^{\prime} /$ are realized as implosives followed by a strongly laryngealized 
vowel: $[\mathfrak{b V}]$ and [aV]. Glottalized velar stops $/ \mathrm{k}^{\prime} /$ are realized either as implosive or ejectives

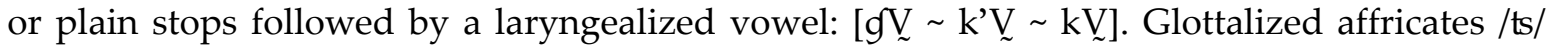
and $/ \mathrm{t} /$ are realized either as ejectives or as plain consonants followed by a laryngealized vowel: $\left[\mathrm{ts}^{\prime} \mathrm{V}_{\sim} \sim \mathrm{ts} V\right]$ and $\left[\mathrm{t}^{\prime} V_{\sim}^{\mathrm{V}} \sim \mathrm{t} / \mathrm{V}\right]$. In syllable-final position, underlying glottalized consonants are deglottalized. Glottal stops are realized with a strong laryngealization of the following vowel as well [?V]. These glottal stops can be of different origins: some of them come from historical plain and glottalized uvular stops * $q$ and * $q$ ', others from glottalized glides * $w$ ' and * $y$ ', and still others from Proto-Tepehua-Totonacan glottal stops *2. We can see that the main phonetic realization of glottalized consonants in Pisaflores Tepehua is laryngealization of the following vowels. However, the base system is not one of modal and laryngealized vowels, but rather one of plain and glottalized consonants, since laryngealization is not found after sonorants and sibilants, as opposed to Zapotitlán de Méndez Totonac.

\section{Apapantilla Totonac}

Apapantilla Totonac belongs to the Northern Totonacan subgroup (Reid \& Bishop 1974, Reid 1991). The authors call the language Xicotepec de Juárez, but the town where the data were collected is Apapantilla (David Beck p.c., 2016). The published dictionary implies a phonological inventory similar to Zapotitlán de Méndez Totonac. The main difference is a five vowel system with mid vowels /e/ and /o/ developed from a combination of high and low vowels, also from high vowels in the context of uvular stops /q/ and velar fricatives /x/. The glottal fricative of Zapotitlán de Méndez Totonac /h/ corresponds to velar fricative / $\mathrm{x} /$ in Apapantilla Totonac, which is (probably) also realized as uvular $[\chi]$.

\begin{tabular}{c|c|c|c|c|c}
\hline \multicolumn{7}{|c|}{ Consonants: } \\
\hline $\mathrm{p}$ & $\mathrm{t}$ & & & $\mathrm{k}$ & $\mathrm{q}$ \\
\hline $\mathrm{t}$ & $\mathrm{ts}$ & $\mathrm{t}$ & $\mathrm{t} t$ & & \\
\hline $\mathrm{m}$ & $\mathrm{s}$ & $\int$ & $\mathrm{t}$ & $\mathrm{x}$ & \\
\hline $\mathrm{w}$ & & $\mathrm{y}$ & $\mathrm{l}$ & & \\
\hline
\end{tabular}

\begin{tabular}{|c|c|c|}
\hline \multicolumn{3}{|c|}{ Vowels: } \\
\hline i, i: & & $\mathrm{u}, \mathrm{u}:$ \\
\hline$\underset{\sim}{\mathrm{i}} \underset{\sim}{\mathrm{i}}$ & & $\underset{\sim}{\mathrm{u}}, \underline{\sim}_{\mathrm{u}}$ \\
\hline e, e: & & $\mathrm{O}, \mathrm{O}:$ \\
\hline e, & & $\mathrm{Q}, \mathrm{Q}:$ \\
\hline & a, a: & \\
\hline & $\underset{\sim}{a}, \underset{\sim}{a}:$ & \\
\hline
\end{tabular}

Below is the statistical distribution of laryngealized and non-laryngealized vowels in initial syllables of the lexical entries found in the Apapantilla dictionary (Reid \& Bishop 1974). Vowel-initial Spanish loans are written etymologically, without laryngealization of the first vowel indicated, and are excluded from statistics. As is explicitly stated in the grammatical sketch (Reid 1991: 2), modal vowels are banned word-initially.

\begin{tabular}{|c|c|c|c|c|c|}
\hline & $\mathrm{p}$ & $\mathrm{t}$ & $\mathrm{k}$ & $\mathrm{q}$ & - \\
\hline$\_\mathrm{V}$ & 262 & 514 & 129 & 126 & $!^{*}$ \\
\hline$\_\mathrm{V}$ & 52 & 116 & 85 & 73 & 492 \\
\hline
\end{tabular}

\begin{tabular}{|r|c|c|c|}
\hline & ts & t & tt \\
\hline$-\mathrm{V}$ & 27 & 71 & 18 \\
\hline$-\mathrm{V}$ & 48 & 86 & 6 \\
\hline
\end{tabular}

\begin{tabular}{|r|c|c|c|c|}
\hline & $\mathrm{s}$ & $\int$ & $\mathrm{t}$ & $\mathrm{x}$ \\
\hline$-\mathrm{V}$ & 43 & 98 & 18 & 33 \\
\hline $\mathrm{V}$ & 12 & 20 & 5 & $!^{*}$ \\
\hline
\end{tabular}

\begin{tabular}{|r|c|c|c|c|c|}
\hline & $\mathrm{m}$ & $\mathrm{n}$ & $\mathrm{l}$ & $\mathrm{w}$ & $\mathrm{y}$ \\
\hline${ }_{\mathrm{V}} \mathrm{V}$ & 473 & 15 & 479 & 22 & 6 \\
\hline $\mathrm{V}$ & 57 & 3 & 49 & 36 & 3 \\
\hline
\end{tabular}


As in Zapotitlán de Méndez Totonac, Apapantilla Totonac bans modal vowels in wordinitial position and laryngealized ones after the velar fricative /x/. Laryngealized vowels after sonorants are more frequent than after sibilants, but less frequent than after stops and affricates: the same pattern is observed in Zapotitlán de Méndez Totonac.

The word for 'road' ('tex) has lost the final vowel in Apapantilla Totonac as well as in the other Northern Totonacan languages; note that the derived form ka:te'xen 'on the road' does not show a laryngealized vowel after the velar fricative $/ x /$. I was able to locate fourteen items with a laryngealized vowel after the velar fricative $/ x /$ in the dictionary; one of them is an ideophonic word, the others are second person subject forms. I give five examples: na'skuxa 'you (sg.) work', nakima:ta:'xiyg 'you (sg.) are going to charge me', ta'xu:pa to'xo:pa 'you (sg.) stay in water', and qe:lo'xoqQ 'loose (of clothes)' (Reid \& Bishop 1974: 94, 306, 402-403). It is possible to phonologize second person subject forms in such a way that eliminates laryngealized vowels after velar fricatives in lexical representations. Alternatively, we can assume that the ban on laryngealized vowels after velar fricatives operated on a proto-level but is not active anymore.

I do not make attempts to incorporate into this study the data of another extensively documented language with laryngealized vowels, Upper Necaxa Totonac (Beck 2004 and 2011; Puderbaugh 2019). This Northern language is an innovative variety of Totonac which has developed glottalized sibilants from initial consonant clusters of the type "sibilant plus uvular stop" (Beck 2006).

\section{Papantla Totonac}

Papantla Totonac is another well documented language of the family, the only one which can boast two dictionaries (Aschmann 1973, García Ramos 2007) and two monographic studies dedicated to its phonology, one of them by a native speaker of the language (García Ramos 1980, Levy 1983). Papantla Totonac has the highest number of speakers in the family, although its dialectal variants have never been studied systematically. In his published dictionary, Herman Aschmann (1973) makes use of the apostrophe to indicate laryngealized vowels, but places it directly after consonants, that is to say, before vowels. Such an odd way of indicating laryngealized vowels is probably meant to show their peculiar phonetic realization in the language. Aschmann follows the same strategy in an unpublished dictionary of Coyutla Totonac (Aschmann 2000). Paulette Levy $(1987,1990)$ follows Aschmann's analysis and postulates a system of modal and laryngealized vowels. The following phonological system is explicitly stated in the work by Paulette Levy (1987: 9) and implicitly assumed in Aschmann's dictionary (1973).

\begin{tabular}{c|c|c|c|c|c|c|}
\hline \multicolumn{7}{|c|}{ Consonants: } \\
\hline $\mathrm{p}$ & $\mathrm{t}$ & & & $\mathrm{k}$ & $\mathrm{q}$ & \\
\hline & $\mathrm{ts}$ & $\mathrm{t}$ & $\mathrm{t}+$ & & & \\
\hline & $\mathrm{s}$ & $\int$ & $\mathrm{t}$ & & & $\mathrm{h}$ \\
\hline $\mathrm{m}$ & $\mathrm{n}$ & & & & & \\
\hline & & & 1 & & & \\
\hline & & & $(\mathrm{r})$ & & & \\
\hline $\mathrm{w}$ & & $\mathrm{y}$ & & & & \\
\hline
\end{tabular}

\begin{tabular}{|l|l|l}
\hline \multicolumn{3}{|c}{ Vowels: } \\
\hline i, i: & & u, u: \\
i, i : $:$ & & u, u: \\
\hline & a, a: & \\
& a, a: & \\
\hline
\end{tabular}

The $/ \mathrm{h} /$ is realized as velar fricative $[\mathrm{x}]$ syllable-initially and as glottal fricative $[\mathrm{h}]$ syllablefinally (Levy 1983: 44). The vibrant / $r$ is found in loanwords and native ideophonic words, hence the use of parentheses (Davletshin 2014). 
We can see that Aschmann proposed the same phonological system for Papantla Totonac and Zapotitlán de Méndez Totonac. However, distributional characteristics of laryngealized vowels are different in Papantla Totonac: phonetic laryngealized vowels are not attested following sonorants $/ \mathrm{m} /, / \mathrm{n} /, / 1 /, / \mathrm{w} /$ and $/ \mathrm{y} /$. Laryngealized vowels are also banned after glottal fricative $/ \mathrm{h} /$. Below is the statistical count of laryngealized and non-laryngealized vowels in initial syllables of the lexical entries from the dictionary of 1973. Laryngealized vowels are more frequent after stops and affricates are more frequent than after sibilants, in accordance with the pattern observed in Zapotitlán de Méndez Totonac and Apapantilla Totonac.

\begin{tabular}{|c|c|c|c|c|c|c|c|c|c|c|c|}
\hline & $\mathrm{p}_{-}$ & $t_{-}$ & $k_{-}$ & $\mathrm{q}_{-}$ & - & & & & $\mathrm{ts}_{-}$ & $t_{-}$ & tt_ \\
\hline${ }_{-} \mathrm{V}$ & 316 & 457 & 121 & 171 & 318 & & & _V & 46 & 61 & 24 \\
\hline$-\mathrm{V}$ & 77 & 93 & 96 & 58 & $!^{*}$ & & & _V & 77 & 86 & 18 \\
\hline & $\mathrm{s}_{-}$ & $\overline{\int_{-}}$ & $t_{-}$ & $\mathrm{h}_{-}$ & & & $\mathrm{m}_{-}$ & $\overline{n_{-}}$ & 1 & $\overline{\mathrm{w}_{-}}$ & $\overline{y_{-}}$ \\
\hline${ }_{-} \mathrm{V}$ & 58 & 66 & 16 & 38 & & ${ }_{-} \mathrm{V}$ & 453 & 31 & 469 & 40 & 4 \\
\hline _V & 11 & 9 & 1 & $!^{*}$ & & _V & $!^{*}$ & $!^{*}$ & $!^{*}$ & $!^{*}$ & $!^{*}$ \\
\hline
\end{tabular}

Again, these statistics are somewhat misleading because some entries in the dictionary contain the same root and, more importantly, the language has a number of highly productive derivational prefixes. All initial vowels are marked as non-laryngealized in the dictionary, but this is just a convention. Paulette Levy (1987: 61-62) states that in word-initial and morphemeinitial (in combinations with certain prefixes) positions vowels automatically acquire either an additional glottal stop, or a hiatus, or glottal stop accompanied by laryngealization, or simply laryngealization. The only lexical entry which starts with a lateral fricative and is followed by a vowel is tit'hu 's/he packs $\mathrm{X}$ with'. This is due to the rarity of $\Psi V$ syllables in Totonacan languages; some more examples of lateral fricatives before laryngealized vowels are found in the dictionary, e.g., 'pata 'hard, tough', qata:'na 'thief', mu:'ktun 'strong unpleasant odour', tu:'tukun 'a kind of tree (Spanish, hoja santa)'.

The main reason for postulating a phonological opposition between modal and laryngealized vowels in Zapotitlán de Méndez Totonac is an even distribution of the laryngealized vowels in relation to their surrounding consonants. Thus, we can reanalyse the phonological system of Papantla Totonac as a system of modal vowels, plain and glottalized consonants: laryngealized vowels are eliminated, but glottalized stops, affricates and sibilants are introduced. It does not seem to be a coincidence that glottal stops are heard preceding vowels and directly following consonants in this language as opposed to Zapotitlán de Méndez Totonac where they are rather heard following vowels, since from a phonological point of view phonetic glottal stops belong to consonants in Papantla Totonac, but to vowels in Zapotitlán de Méndez Totonac.

\begin{tabular}{c|c|c|c|c|c|c|}
\hline \multicolumn{7}{|c|}{ Consonants: } \\
\hline $\mathrm{p} \mathrm{p}^{\prime}$ & $\mathrm{t}, \mathrm{t}^{\prime}$ & & & $\mathrm{k}, \mathrm{k}^{\prime}$ & $\mathrm{q}, \mathrm{q}^{\prime}$ & \\
\hline & $\mathrm{ts}, \mathrm{ts}^{\prime}$ & $\mathrm{t}, \mathrm{t}^{\prime}$ & $\mathrm{t} t, \mathrm{t}^{\prime}$ & & & \\
\hline & $\mathrm{s}, \mathrm{s}^{\prime}$ & $\int, \rho$ & $\mathrm{t}, \mathrm{t}^{\prime}$ & & & $\mathrm{h}$ \\
\hline $\mathrm{m}$ & $\mathrm{n}$ & & & & & \\
\hline & & & 1 & & & \\
\hline & & & $(\mathrm{r})$ & & & \\
\hline $\mathrm{w}$ & & $\mathrm{y}$ & & & & \\
\hline
\end{tabular}

\begin{tabular}{|c|c|c|}
\hline \multicolumn{3}{|c|}{ Vowels: } \\
\hline i, i: & & u, u: \\
\hline & a, a: & \\
\hline
\end{tabular}


Ejective fricatives are relatively rare sounds in the world's languages, but 18 of them are reported in the paper by Ryan Shosted and Sharon Rose (2011: 41-42). Importantly, at least one language, Lakota, has plain and glottalized stops, affricates and sibilants in its inventory, but the contrast is neutralized in sonorants, similarly to Papantla Totonac (Ingham 2003: 4).

Interestingly enough, a native speaker of the language Cresencio García Ramos (1980: 23, 2007: 50) postulates a system of plain and glottalized stops and affricates, in addition to glottal stop. I first met Cresencio García Ramos in 2007; his glottalized stops and affricates were very clearly audible, sounding nothing like plain consonants followed by laryngealized vowels. I suppose that this particular pronunciation is due to his dialect. The lack of glottalized sibilants in his works might be a dialectal trait too, or, alternatively, it might represent an unrecognized contrast. I wish I had taken Cresencio García Ramos's native-speaker intuition more seriously when I first met him. On the other hand, the recordings published by Paulette Levy (2012) do not show any phonetic glottalized consonants, but rather clear laryngealized vowels. In his phonetic study of Papantla Totonac, Rafael Alarcón Montero (2008: 96-98) mentions ejective stops as an alternative realization of laryngealized vowels and attributes it to dialectal variation.

The rules for the developments in Papantla Totonac can be presented as follows:

$$
{ }^{*} \mathrm{RV} \rightarrow \mathrm{RV} ;{ }^{*} \mathrm{~T}(\mathrm{~S}) \underset{\sim}{\mathrm{V}} \rightarrow \mathrm{T}(\mathrm{S})^{\prime} \mathrm{V},{ }^{*} \mathrm{SV} \rightarrow \mathrm{S}^{\prime} \mathrm{V}
$$

( $\mathrm{R}$ stands here for any sonorant, $\mathrm{S}$ for any sibilant and $\mathrm{T}$ for any stop).

Laryngealized vowels carry a low lexical load in Papantla Totonac (Aschmann 1973: vii). None of the minimal pairs involve laryngealized vowels following sonorants.

ifla'kan 'theirs'

'tkaka 'ashes'

fa'pafni 'dirty one'

'kuta 'sour'

'stapu 'biting midge'

'tsitsi 'furuncle' iflakan 'his face'

'tkaka 'spicy'

fa'pafni 'the washed one'

'kuta 's/he unties X'

'stapu 'beans'

'tsitsi 'warm, tepid (of water)'

The comparison of three languages - Papantla Totonac, Apapantilla Totonac and Zapotitlán de Méndez Totonac - suggests that Papantla Totonac has lost the opposition between modal and laryngealized vowels after sonorants. This loss resulted in the restructuring of the phonological system and in the development of glottalized stops, affricates and sibilants. The sound shift under discussion is easy to explain because glottalized stops, sibilants and sonorants are articulated differently - the sonorants, in particular, are produced with closer constriction of the vocal folds which interrupts or modifies normal voicing, but with neither a raising nor a lowering movement of the larynx: acoustically, they can be described as laryngealized or creaky voice sonorants (Ladefoged \& Maddieson 1996: 78; Maddieson 2013). The lack of minimal pairs for modal and laryngealized vowels following sonorants and the ban on modal vowels after sonorants in word-final position in Proto-Totonacan might facilitate the loss of the contrast after sonorants.

\begin{tabular}{|c|c|c|c|c|}
\hline & Papantla & Zapotitlán & Apapantilla & Misantla \\
\hline 's/he loosens X' & Jl'ha & Jlahay & Ja'xa & - \\
\hline 'turkey hen' & ta:wila & tfuwila & ta:wila & ta:wa'la? \\
\hline 'wild tamarind' & 'ili:q & lili:iqa & la'la:k & la:la:k \\
\hline 'butterfly' & fpipilitiq & Spipili:qa & fpipille:q & 'jpipi \\
\hline
\end{tabular}




\begin{tabular}{|c|c|c|c|c|}
\hline & Papantla & Zapotitlán & Apapantilla & Misantla \\
\hline 'heron' & 'lu:qu & lu:qu & 'lo:qo & - \\
\hline 'clothes' & 'lufu & $\operatorname{lu} \underset{\sim}{u}$ & 'luㅢㅆㅡ & - \\
\hline 'long' & tma:n & tma:n & 'tma:n & tma:n \\
\hline 'be lying (supine)' & -'ma:- & $-m a:-$ & -'ma:- & -'ma:- \\
\hline 'bamboo (Spanish, tarro)' & mattu:k & mattu:k & 'mattu:k & - \\
\hline 'jug' & 'ttamank & ttamank & ttámank & 'tami:nk \\
\hline 's/he pours on, waters X' & mu'nu & munuy & múnu & - \\
\hline 'nine' & -na'hatsa & -naha:tsa & $-n a_{\sim}^{\prime} x a: s$ & -na'ha:tsa \\
\hline 's/he winds or twists X' & 'snata & snata & 'snata & - \\
\hline 'vein, nerve' & 'nuhut & fnuhut & fno'xot & - \\
\hline 's/he eats' & wa:'yan & wa:yan & was'yan & wa:'yan \\
\hline 'mealing stone (Spanish, metate)' & 'fwa:ti & fwa:ti $\underset{\sim}{i}$ & 'fwa:ti & 'fwa:t \\
\hline 'egg' & 'qatwa:t & qa:twa:t & qa'twa:t & qa:q'tuwa:t \\
\hline 'you (sg.)' & wif & wif & 'wif & wi \\
\hline 'guava' & a:'siwi:t & a:siwi:t & a:si'wi:t & $\underset{\sim}{\text { a:'siwi:t }}$ \\
\hline 'immature ear of maize (Spanish, jilote)' & 'izwi:t & fiwi:t & fi'wi:t & 'fiwi:t \\
\hline 'cool' & sqàiwiwi & sqąwiwi & sqęwiwiwi & - \\
\hline 'hawk' & wa:ya & wa:ya & $w \underset{\sim}{2} y \underset{\sim}{\prime}$ & - \\
\hline 'earth' & 'tiyat & tiyat & 'tiyat & 'tiyat \\
\hline 'squirrel' & 'staya & stayi & 'stayi & - \\
\hline 'mouse' & 'tsi:ya & tsiiga & 'tsi:ya & 'tsiw \\
\hline
\end{tabular}

Word-initial palatal glides are extremely rare in Tepehua-Totonacan languages and are probably of secondary origin. I was unable to find other examples of Proto-Totonacan * ya and * yu with cognates in Papantla Totonac.

Laryngealized vowels after sonorants in Apapantilla Totonac, Zapotitlán de Méndez Totonac and Misantla Totonac are lexically determined. Papantla Totonac forms a relatively shallow subgroup together with the languages of Southern Sierra, Zapotitlán de Méndez Totonac and Olintla are among them (see Figure 1). Thus, the loss of laryngealization after sonorants in Papantla Totonac is an innovation. In Proto-Totonacan final vowels in nominals after both sonorants and fricatives were obligatorily laryngealized (Davletshin 2018: 161). This situation is preserved in Apapantilla Totonac and Zapotitlán de Méndez Totonac; its reflexes are also found as final glottal stops in Coatepec Totonac, Huehuetla Totonac and Olintla Totonac, and as glottalization of final vowel-preceding consonants in Filomeno Mata (for the data see McQuown 1990, Troani 2004, McFarland 2009). In Papantla Totonac, final vowels after sibilants in nominals are laryngealized but sonorants are followed by modal vowels word-finally. Laryngealized nominal-final vowels after sonorants and fricatives are probably due to a single sound change. The ban on final laryngealized vowels after sonorants and the ban on final modal vowels after fricatives in Papantla Totonac imply that the rule of laryngealization of final vowels chronologically preceded the loss of laryngealization after sonorants; thus, they also imply that the system of glottalized stops, affricates and sibilants attested in Papantla Totonac is an innovation.

According to Aschmann (1946: 42), laryngealized vowels in Coyutla Totonac are realized with a glottal stop preceding the vowel, similarly to Papantla Totonac. If our suggestion is cor- 
rect, the distribution of laryngealized vowels in Coyutla Totonac should be uneven, depending on preceding consonants. An unpublished dictionary of Coyutla Totonac was posted on-line (Aschmann 2000). Predictably, this dictionary of some 6000 lexical entries does not include any entries with laryngealized vowels following sonorants in initial syllables.

\section{Misantla Totonac}

Misantla Totonac is a member of the Totonacan subgroup but is separated from all the other Totonacan languages genetically, both from grammatical and lexical points of view. It is also isolated from the other languages of the family geographically. Today, this language is spoken in two towns of Yecuatla and San Marcos Atesquilapan, Veracruz, and considerable dialectal differences between the two towns have been attested. The language is highly endangered, with fewer than 133 speakers, most of whom are elderly (according to census of 2010). The language is intensively studied in works by Carolyn MacKay and Frank Trechsel, although its lexicon remains underdocumented (MacKay 1994b, 1999; MacKay \& Trechsel 2005; Castro Guevara 2011). It should be mentioned that Carolyn MacKay's grammar of 1999 was a very important contribution to Totonacan studies. In a phonological sketch of Misantla Totonac, MacKay (1994b: 370) gives the following system.

\begin{tabular}{c|c|c|c|c|c|c|}
\hline \multicolumn{7}{|c|}{ Consonants: } \\
\hline $\mathrm{p}$ & $\mathrm{t}$ & & & $\mathrm{k}$ & $\mathrm{q}$ & ? \\
\hline & $\mathrm{ts}$ & $\mathrm{t}$ & & & & \\
\hline & $\mathrm{s}$ & $\int$ & $\mathrm{t}$ & & & $\mathrm{h}$ \\
\hline $\mathrm{m}$ & $\mathrm{n}$ & & & & & \\
\hline & & & 1 & & & \\
\hline $\mathrm{w}$ & & $\mathrm{y}$ & & & & \\
\hline
\end{tabular}

\begin{tabular}{|c|c|c}
\hline \multicolumn{3}{|c}{ Vowels: } \\
\hline $\mathrm{i}, \mathrm{i}:$ & & $\mathrm{u}, \mathrm{u}:$ \\
$\mathrm{i}, \mathrm{i}: \mathrm{u}, \mathrm{u}:$ & & \\
\hline & & \\
& $\mathrm{a}, \mathrm{a}:$ & \\
& $\mathrm{a}, \mathrm{a}: \mathrm{a}$ & \\
\hline
\end{tabular}

Neither MacKay nor most other Totonacanists incorporate Spanish loans and native ideophonic words into the phonological system (MacKay 1994b: 386). Glottal stop has a peculiar distribution in the language: it only occurs word-finally after short vowels, and all syllableinitial glottal stops can be interpreted as epenthetic (MacKay 1994b: 382). Remarkably, the vowel after a glottal stop is always laryngealized, and the vowel before a glottal stop is always stressed. If $/ \mathrm{R} /$ is not word-final (for example, when followed by a suffix), then it is deleted (MacKay 1994b: 400).

MacKay (1999: 384-385, also Trechsel \& Faber 1992) emphasizes that the contrasts between long and short vowels and between plain and laryngealized vowels are established by numerous minimal pairs in Misantla. However, neither of their minimal pairs shows any contrast between modal and laryngealized vowels after sibilants or sonorants.

'sta:nit 's/he sold $\mathrm{X}$ for $\mathrm{Y}$ '

kili'tiyat 'my land'

'tfi:n 'strong, very'

tu'ty 's/he sucks $X$ ' 'sta:nit 's/he looked at X'

kili:'tiyat 'my girlfriend'

'tfi:n 'pus'

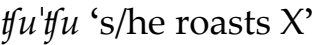

Laryngealized vowels of initial syllables show a rather intriguing distribution in a published word-list of some 700 lexical items (MacKay \& Trechsel 2005). 


\begin{tabular}{|c|c|c|c|c|c|c|c|c|c|c|c|}
\hline & $\mathrm{p}_{-}$ & $t_{-}$ & $\mathrm{k}_{2}$ & $\mathrm{q}_{-}$ & - & & & & & ts_ & $t_{-}$ \\
\hline _V & 53 & 78 & 27 & 23 & 1 & & & & _V & 11 & 25 \\
\hline _V & 6 & 14 & 20 & 18 & 45 & & & & _V & 21 & 11 \\
\hline & $\mathrm{s}_{-}$ & $\int_{-}$ & $4_{-}$ & $\mathrm{h}_{\text {- }}$ & & & $\mathrm{m}_{-}$ & $\mathrm{n}_{-}$ & 1 & $\mathrm{w}_{-}$ & $\mathrm{y}_{-}$ \\
\hline _V & 19 & 19 & 7 & 10 & & -V & 104 & 9 & 65 & 5 & 3 \\
\hline _V & 2 & 1 & 0 & 1 & & _V & 2 & 2 & 5 & 8 & 1 \\
\hline
\end{tabular}

The only example of a syllable-initial modal vowel must be a typo (see a loan from Spanish espeho 'mirror') because the rule of automatic glottal stop insertion before a syllable-initial vowel and its subsequent laryngealization is explicitly stated in the phonological sketch. Laryngealized vowels are frequent after stops and affricates, but few words show laryngealized vowels after sonorants and sibilants in the word-initial syllable. However, laryngealization of vowels after sonorants is an important marker of the second person subject on verbs (MacKay 1999: 156-160) and the rule of the laryngealization of final vowels after sonorants in nominals is easily recognizable in the published wordlist.

Two words show a laryngealized vowel after a syllable-initial /h/: 'hin 'smoke' and ta'hi:n 'thunder'. This is unusual because the other languages of the family do not allow laryngealization in this position.

\begin{tabular}{c|c|c|c|c}
\hline & Misantla & Zapotitlán & Apapantilla & Papantla \\
\hline 'smoke' & 'hin & hini $\underset{\sim}{ }$ & 'hini & 'hin \\
\hline 'thunder' & ta'hi:n & - & ta:'hi:n & ta'hi:n \\
\hline
\end{tabular}

MacKay (1994b: 384) stresses that, although laryngealized vowels most frequently occur after obstruents, they also occur following sonorants. However, she does not mention that very few items show a laryngealized vowel following a sibilant: $m i$ 'sin 'jaguar', 'sak 's/he brings $X$ together', 'sin 'rain' and 'fu: 'n 'bitter'. Five out of six words with a laryngealized vowel following a fricative show a dental nasal. This suggests that laryngealization in these words can be reinterpreted in a different way, for example, as surface realization of the underlying final glottalized nasal. We should take into consideration the fact that some of the items might be typos, for example, 's/he chooses' is given in the word-list as lak'sak but contains the same root as 'sak 's/he brings $X$ together'. Alternatively, some of these words might have been elicited from an overlaryngealizing speaker, for example, an elderly person. Carlo Antonio Castro Guevara's dictionary (2011) does not help much, because the author worked with the consultants from Misantla, who were likely to speak a particular dialect, different from Yecuatla and San Marcos Atesquilapan. He only heard laryngealized vowels after stops and affricates; no laryngealized vowels following sonorants and fricatives are found in his dictionary.

Interestingly enough, only one out of five words with a laryngealized vowel following a fricative, 'bitter', consistently shows a laryngealized vowel in the other languages of the family.

\begin{tabular}{|c|c|c|c|c|}
\hline & Misantla & Zapotitlán & Apapantilla & Papantla \\
\hline 'jaguar' & mi'sin & $\begin{array}{c}\text { stakku: misin } \\
\text { 'ocelot' }\end{array}$ & mi'sin & $\begin{array}{l}\text { mi'sin 'kiwwi } \\
\text { 'a kind of tree' }\end{array}$ \\
\hline 'to bring together' & $s \underset{\sim}{a-}$ & sak- & sak- & sak- \\
\hline 'downpour' & si:n & $\sin$ & ta:sait:n & 'sĩ:n, 'se:n \\
\hline 'bitter' & 'fu:n & $\int \underset{\sim}{u}: n$ & 'fu:ni & 'us:n \\
\hline
\end{tabular}


I do not include here the word 'six', which is given as -tfa:' $\int_{a n}$ in the wordlist but as - $f a$ :'fan elsewhere (MacKay \& Trechsel 2005: 315, 237, 238). Its cognates do not show laryngealization either.

The transcription of the Misantla Totonac word 'si:n 'downpour' is given as ['se:n], where the mid vowel is not accounted for by the postulated allophonic rules (MacKay \& Trechsel 2005: 294). The set 'rain, downpour' deserves some comments. First, Zapotitlán de Méndez Totonac and Coahuitlan Totonac do not show laryngealization in this word (Moore 2017: 100). Second, the mid vowels are surface allophones of high vowels in the vicinity of uvulars in Papantla Totonac and Misantla Totonac, which means that the form ['se:n] should be phonologized as sa'in or sa'in, cf. Apapantilla Totonac ta:sa'in. Two alternative realizations in Filomeno Mata Totonac sa?in sa'yin correspond to two alternative forms 'se:n 'si:n in Papantla Totonac (McFarland 2009: 14). Third, the sequences /iy/, /yi/ and /uw/, /wu/ are banned in Totonacan languages, and all lexical and grammatical morphemes in proto-Tepehua-Totonacan had consonantal onsets, including those with a glottal stop which shifted to a palatal glide following a vowel (Davletshin 2019). Thus, a likely reconstruction of the word is * si'?an, cf. also Pisaflores Tepehua si:ni: 'the chief of Thunders', etymologically 'one who makes downpours to come' (author's fieldwork from 2011). The glottal stop *? disappears in many languages but results in laryngealization of the vowel in Apapantilla Totonac, Papantla Totonac and Misantla Totonac, because vowels after (phonetic) glottal stops are laryngealized in Tepehua-Totonacan languages. The high vowel /i/ and the low vowel /a/ coalesced, resulting in a long and mid vowel [e:] as the regular surface realization.

On the other hand, eleven words which consistently show laryngealized vowels after sibilants in the other languages of the family do not have laryngealization in Misantla Totonac, with the exception of 'yun 'bitter'.

\begin{tabular}{|c|c|c|c|c|}
\hline & Misantla & Zapotitlán & Apapantilla & Papantla \\
\hline 'flower' & 'Janat & fanat & fánat & Janat \\
\hline 'grand-' & $-' f u: n$ & -funa:- & -fuya:- & -'sũn \\
\hline 'hole' & tu'kuk & tukuku & túk kuku & tu'kuku \\
\hline 'sweat lodge' & li:fa:'qi:n & farqa & 'aa:q & 'á:qa \\
\hline 'sweet' & 'siksi & saqssi & 'seqsi & 'sąqsi $\underset{\sim}{i}$ \\
\hline 's/he blows X' & su'nu? & sunuy & sünu & sünu \\
\hline 'tongue' & -si:ma'qa:t & -si:maqa:t & -si:máqaa:t & -si:ma'qa:t \\
\hline 's/he has an itch' & 'fin & $\int_{\underline{2}}$ & - & ' $\int_{i n}$ \\
\hline 'nail' & -ma'qasi:h & -siyan & -maq'sinn & -sihhan \\
\hline 'squash' & 'nipfi & $n i p f \underset{\sim}{1}$ & nipfi্ & 'nipfi \\
\hline 'bitter' & 'ux:n & fün & 'fu:ni & ' \\
\hline
\end{tabular}

For Papantla Totonac 'Ja:qa 'sweat lodge', see the wordlist published by Paulette Levy (1990: 164).

To sum up, Misantla Totonacan laryngealized vowels after sibilants correspond to modal vowels in other Totonacan languages, and laryngealized vowels after sibilants in other Totonacan languages correspond to modal vowels in Misantla Totonac. This implies that laryngealized vowels after sibilants have become neutralized with modal vowels in Misantla, since laryngealized vowels after sibilants are lexically determined in Totonacan languages. It is likely that Totonacan laryngealized vowels after sibilants come from two different sources. First, in Proto-Totonacan nominals, the final vowels after sibilants and sonorants were laryngealized (according to the rule of laryngealization for final vowels). Second, laryngealized vowels after sibilants in initial syllables most likely developed from combinations of glottal 
stop-initial roots with the sibilant prefixes of size and intensity ${ }^{*} s_{-},{ }^{*}$ - and ${ }^{*} 4$ - (Davletshin 2019). Misantla split first from the other Totonac languages, and so we can assert that laryngealized vowels after sibilants had never developed in that language: Misantla may have eliminated the glottal stop ${ }^{*} ?$ in the clusters ${ }^{*} s ?, * / 2$ and ${ }^{*}+2$ in the same way as it happened in Tepehua languages. However, Misantla has lost laryngealization in the vowels after sibilants in word-final position as well, even though word-final vowels after sonorants are always laryngealized. ${ }^{4}$ It should be mentioned that in Misantla Totonac word-final vowels were lost after fricatives and sonorants (Davletshin 2018: 166). However, in a few cases, when the vowel was preceded by a sequence of two consonants, it was preserved anyway.

\begin{tabular}{c|c|c|c|c}
\hline & Misantla & Zapotitlán & Apapantilla & Papantla \\
\hline 'sweet' & 'siksi & saqsi $\underset{\sim}{i}$ & 'seqsi & 'saqsi $\underset{\sim}{i}$ \\
\hline 'squash' & 'nipfi & nip $\underset{\sim}{i}$ & 'nip $\underset{\sim}{i}$ & 'nipfi \\
\hline
\end{tabular}

Again, laryngealized final vowels after sonorants and fricatives are probably due to a single sound change. The ban on final laryngealized vowels after sibilants and the ban on the final modal vowels after sonorants in Misantla Totonac imply that the rule of laryngealization for final vowels preceded the loss of laryngealization after sibilants. Importantly, it means that laryngealized vowels after sibilants are to be reconstructed for the Proto-Totonacan level. An additional argument is that two words seem to demonstrate migration of laryngealization from the vowel after a sibilant to the following syllable: 'fanat 'flower', cf. *'Ranat, and su'nu? 's/he blows X', cf. *s?unu- 'to blow X'. It is also important to mention that laryngealization of the second person subject verbal forms does not involve vowels following sibilants, or other obstruents in Misantla (MacKay 1999: 156-160).

It is easy to figure out what could have been the motivation for the loss of laryngealized vowels after sibilants. Relatively few of the world's languages possess glottalized sibilants, probably because of an articulatory conflict: an ejective requires increased intraoral pressure and a fricative requires air to be continuously vented through a narrow constriction (Shosted \& Rose 2011: 41-42).

The rules for the development of Misantla Totonac can be presented as follows.

${ }^{*} \mathrm{~S} \underset{\sim}{\mathrm{V}} \rightarrow \mathrm{SV} ;{ }^{*} \mathrm{~T}(\mathrm{~S}) \underset{\sim}{\mathrm{V}} \rightarrow \mathrm{T}(\mathrm{S}){ }^{\prime} \mathrm{V},{ }^{*} \mathrm{RV} \rightarrow \mathrm{R}{ }^{\prime} \mathrm{V}$,

(R stands here for any sonorant, $\mathrm{S}$ for any sibilant and $\mathrm{T}$ for any stop.)

Accepting the loss of laryngealization after sibilants in Misantla Totonac, we automatically imply the existence of a system of modal vowels, plain consonants, and glottalized consonants at a certain period in history, when laryngealized vowels are eliminated, but glottalized stops, affricates, and sonorants are introduced in their place.

\begin{tabular}{|c|c|c|c|c|c|c|}
\hline \multicolumn{7}{|c|}{ Consonants: } \\
\hline $\mathrm{p}, \mathrm{p}^{\prime}$ & $\mathrm{t}, \mathrm{t}^{\prime}$ & & & $\mathrm{k}, \mathrm{k}^{\prime}$ & $\mathrm{q}, \mathrm{q}^{\prime}$ & $\mathrm{l}$ \\
\hline & $\mathrm{ts}, \mathrm{ts}^{\prime}$ & $\mathrm{t}, \mathrm{t}^{\prime}$ & & & & \\
\hline & $\mathrm{s}$ & $\int$ & $\mathrm{t}$ & & & $\mathrm{h}$ \\
\hline $\mathrm{m}, \mathrm{m}^{\prime}$ & $\mathrm{n}, \mathrm{n}^{\prime}$ & & & & & \\
\hline & & & $\mathrm{l}, \mathrm{l}^{\prime}$ & & & \\
\hline $\mathrm{w}, \mathrm{w}^{\prime}$ & & $\mathrm{y}, \mathrm{y}^{\prime}$ & & & & \\
\hline
\end{tabular}

\begin{tabular}{|l|l|l|}
\hline \multicolumn{3}{|c|}{ Vowels: } \\
\hline $\mathrm{i}, \mathrm{i}:$ & & $\mathrm{u}, \mathrm{u}:$ \\
\hline & $\mathrm{a}, \mathrm{a}:$ & \\
\hline
\end{tabular}

4 The rule is not stated explicitly in the grammar but can be easily deduced from the published wordlist (MacKay \& Trechsel 2005). 
Interestingly, in the recordings of Misantla Totonac published by Carolyn MacKay (2012) laryngealization on vowels following stops and affricates is often heard close to the preceding consonant - a situation reminiscent of the one described by Herman Aschmann for Coyutla Totonac.

It is possible that after the loss of laryngealization in vowels after sibilants had been completed in Misantla Totonac, some new laryngealized vowels were introduced from other sources for the words 'hin 'smoke', mi'sin 'jaguar', ta'hi:n 'thunder' and 'fu:n 'bitter'. I was unable to find any specific conditions which might be responsible for the new laryngealized vowels ${ }^{5}$. The comparisons suggest that we need a further study of Misantla Totonacan laryngealized vowels after fricatives, perhaps involving the use of instrumental phonetic methods. Such a study is made all the more urgent by the fact that Misantla Totonac is a highly endangered language.

\section{Conclusions}

Analysis of the distribution of laryngealized and plain vowels relative to preceding consonants in Totonacan languages results in several findings, some of them of considerable typological interest. First, in at least three Totonacan languages, laryngealized vowels are banned following the glottal fricative or its phonetic reflexes. Second, Papantla Totonac and Coyutla Totonac can be described as systems of plain and glottalized stops, affricates and sibilants. This system developed from an earlier contrast between modal and laryngealized vowels. Third, Misantla Totonac can be described as having a system of plain and glottalized stops, affricates and sonorants, at least when viewed in comparative and historical perspective. This system, too, has developed from an earlier system of modal and laryngealized vowels. It is possible to show that both Papantla Totonac and Misantla Totonac are innovative in this respect, and, correspondingly, Apapantilla Totonac and Zapotitlán de Méndez Totonac preserve the original system of modal and laryngealized vowels. Thus, these two languages are of special importance for the reconstruction of proto-Totonacan laryngealized vowels.

It is expected that laryngealized vowels tend to evolve differently depending on the preceding consonants, since glottalized stops, sibilants and sonorants involve different mechanisms of articulation. An unexpected finding is that laryngealized vowels can result in the development of glottalized consonants.

From the acoustic point of view, phonologically glottalized consonants in Papantla Totonac and Misantla Totonac (and in some Tepehua languages) are plain consonants followed by laryngealized vowels. Cross-linguistically, this is quite unusual. It is possible that laryngealized stops, affricates and sibilants might be a better term to describe them, allowing us to distinguish them from phonetically ejective consonants - hence the title given to the present paper.

\section{Acknowledgements}

My special thanks go to the speakers of Tepehua and Totonac languages for their knowledge, food and affection, in particular, my mentor Conrado García. I am very grateful to fellow Totonacanists for advice, heated debates and data that are so hard to get in the field: Carlos Gua-

${ }^{5}$ It is tempting to suggest that laryngealization in at least two examples come from the lost final vowel: 'hin 'smoke', cf. *hini?, and 'fu:n 'bitter', cf. */2u:ni?. However, some counterexamples do not allow me to postulate such a rule: 'tfin 'pus', cf. *tfina?. The word mi'sin 'jaguar' would not be covered by this development. 
dalupe Heiras Rodríguez, David Beck, Dorothy Herzog, Jim Watters, Jorge Tino, Michelle Gracía-Vega, Paulette Levy, Søren Wichmann and Susan Smythe Kung. Last but not least, Mikhail Zhivlov was always ready to discuss Totonacan reconstructions, while the Nostratic seminar in Moscow kindly hosted several of my talks on Tepehua-Totonacan languages.

\section{References}

Alarcón Montero, Rafael. 2008. Indicios acústicos de las vocales rechinadas del totonaco. In: Pedro Martín Butragueño \& Esther Herrera Zendejas (coords.). Fonología instrumental: patrones fónicos y variación, 89-105. México: El Colegio de México.

Arana Osnaya, Evangelina. 1953. Reconstrucción del proto-totonacano. In: Ignacio Bernal \& Eusebio Dávalos Hurtado (eds.). Huastecos, totonacos y sus vecinos / Revista mexicana de estudios antropológicos 13(2/3): 123-130.

Aschmann, Elizabeth D. 1984. The relative clause in Highland Totonac. SIL Mexico Workpapers 6: 1-27.

Aschmann, Herman P. 1946. Totonaco phonemes. International Journal of American Linguistics 12(1): 34-43.

Aschmann, Herman P. 1962. Vocabulario totonaco de la sierra. Serie de vocabularios indigenas "Mariano Silva y Aceves", vol. 7. Instituto México: Instituto Lingüístico de Verano.

Aschmann, Herman P. 1973. Diccionario totonaco de Papantla. Vocabularios y Diccionarios Indígenas "Mariano Silva y Aceves" vol. 16. México: Instituto Lingüístico de Verano.

Aschmann, Herman P. 1983. Vocabulario totonaco de la sierra. Serie de vocabularios indígenas "Mariano Silva y Aceves", vol. 7. Segunda edición. México: Instituto Lingüístico de Verano.

Aschmann, Herman P. 2000. Coyutla Dictionary. Bartholomew Collection of Unpublished Materials SIL International, Mexico Branch. Available at: www.sil.org/resources/language-culture-archives.

Aschmann, Herman P., William L. Wonderly. 1952. Affixes and implicit categories in Totonac verb inflection. International Journal of American Linguistics 18(3): 130-145.

Beck, David. 2004. Upper Necaxa Totonac. Munich: Lincom.

Beck, David. 2006. The emergence of ejective fricatives in Upper Necaxa Totonac. University of Alberta Working Papers in Linguistics 1. Available at: http://www.linguistics.ualberta.ca/UAWPL voll.cfm.

Beck, David. 2011. Upper Necaxa Totonac dictionary. Berlin: Mouton de Gruyter.

Brown, Cecil H., David Beck, Grzegorz Kondrak, James K. Watters, Søren Wichmann. 2011. Totozoquean. International Journal of American Linguistics 77(3): 323-372.

Castro Guevara, Carlo Antonio. 2011. Léxico misanteca. México: IIA-UNAMU.

Christiansen, Landis G. 1937. Totonaco. Investigaciones lingüísticas 4: 151-153.

Davletshin, Albert. 2014. Los sustantivos, adverbios y adjetivos ideofónicos en el tepehua de Pisaflores, Veracruz, México. Ponencia presentada en el Primer Congreso Internacional de Investigaciones sobre el Mundo Totonaco, Lipuntahuaca Huehuetla, Puebla, 27-29 de agosto, 2014.

Davletshin, Albert. 2016. Glottalization of stops and affricates in San Pedro Tziltzacuapan Tepehua, Veracruz, Mexico. Paper presented at the II Workshop on the Sound Systems of Mexico and Central America, Mexico City, March 30 - April 1.

Davletshin, Albert. 2018. Las vocales finales, los procesos fonéticos finales y mediales en el protototonaco-tepehua: un primer acercamiento. In: Elsa Cristina Buenrostro, Lucero Meléndez Guadarrama, Marcela San Giacomo Trinidad (eds.). Lingüística histórica de lenguas indomexicanas: hallazgos y discusiones recientes: 139-186. IIA-UNAM: México.

Davletshin, Albert. 2019. Some Topics in Tepehua-Totonac Historical Phonology (Hекоторые вопросы исторической фонетики тепеуа-тотонакских языков). М.A. Dissertation. Moscow, Russian State University for the Humanities.

Fallon, Paul D. 2002. The Synchronic and Diachronic Phonology of Ejectives. New York: Routledge.

García Ramos, Crescencio. 1979. Fonología del totonaco del Tajín, Veracruz. Cuadernos Antropológicos (Veracruz) 2: 133-176.

García Ramos, Crescencio. 2007. Diccionario básico: totonaco-español y español-totonaco. Xalapa: Academia Veracruzana de las Lenguas indígenas, Secretaría de Educación de Veracruz.

García Rojas, Blanca Rosa. 1978. Dialectología de la zona totonaco-tepehua. Tesis de licenciatura. México. Escuela Nacional de Antropología e Historia. 
Herrera Zendejas, Esther. 2009. Formas sonoras: mapa fónico de las lenguas mexicanas. México: El Colegio de México. Ingham, Bruce. 2003. Lakota. Languages of the World Materials 426. Munich: Lincom.

Ladefoged, Peter, \& Ian Maddieson. 1996. The Sounds of the World's Languages. Oxford: Blackwell Publishers.

Levy, Paulette. 1987. Fonología del totonaco de Papantla, Veracruz. México: UNAM.

Levy, Paulette. 1990. Totonaco de Papantla, Veracruz. Archivo de Lenguas Indígenas de México. México: El Colegio de México.

Levy, Paulette. 2012. Totonaco de Papantla: El Cerro del Carbón. In: Paulette Levy \& David Beck (ed.). Las lenguas totonacas y tepehuas: Textos y otros materiales para sus estudios: 345-466. México: UNAM.

Levy, Paulette, David Beck (ed.). 2012. Las lenguas totonacas y tepehuas: Textos y otros materiales para sus estudios. México: UNAM.

MacKay, Carolyn J. 1994a. Prospects and proposals for Totonacan research. In: Leonardo Manrique, Yolanda Lastra, Doris Bartholomew (eds.). Panorama de los estudios de las lenguas indígenas de México. T. 1. Colección Biblioteca Abya-Yala, 16, 137-168. Quito, Ecuador: Ediciones Abya-Yala.

MacKay, Carolyn J. 1994b. A sketch of Misantla Totonac phonology. International Journal of American Linguistics 60(4): 199-248.

MacKay, Carolyn J. 1999. A Grammar of Misantla Totonac. Salt Lake City: University of Utah Press.

MacKay, Carolyn J. 2011. Una reconstrucción del acento primario en el proto-totonaco-tepehua. In: Ana Lidia Munguía Duarte (ed.). Colección de Estudios Lingüísticos I. Fonética, morfología y tipología semántico-sintáctica: 93-125. Hermosillo: Universidad de Sonora.

MacKay, Carolyn J. 2012. Totonaco de Misantla, Veracruz. In: Paulette Levy, David Beck (eds.). Las lenguas totonacas y tepehuas: Textos y otros materiales para sus estudios: 116-180. México: UNAM.

MacKay, Carolyn J., Frank R. Trechsel. 2005. Totonaco de Misantla, Veracruz. Archivo de Lenguas Indígenas de México. El Colegio de México: México.

MacKay, Carolyn J., Frank R. Trechsel. 2018a. An alternative reconstruction of Proto-Totonac-Tepehua. International Journal of American Linguistics 84 (1): 51-92.

MacKay, Carolyn J., Frank R. Trechsel. 2018b. Una reconstrucción alternativa del protototonaco-tepehua. In: Elsa Cristina Buenrostro, Lucero Meléndez Guadarrama, Marcela San Giacomo Trinidad (eds.). Lingüística histórica de lenguas indomexicanas: hallazgos y discusiones recientes: 85-123. México: IIA-UNAM.

Maddieson, Ian. 2013. Glottalized Consonants. In: Matthew S. Dryer, Martin Haspelmath (eds.). The World Atlas of Language Structures Online. Leipzig: Max Planck Institute for Evolutionary Anthropology. Available online at http://wals.info/chapter/7.

McFarland, Teresa. 2009. The Phonology and Morphology of Filomeno Mata Totonac. Ph.D. Dissertation, University of California, Berkeley.

McQuown, Norman A. 1990. Gramática de la lengua totonaca (Coatepec, Sierra Norte de Puebla). México: UNAM.

Moore, Devin. 2017. Subgrouping of Coahuitlán Totonac. Canadian Journal of Linguistics / Revue canadienne de linguistique 62(1): 84-117.

Nida, Eugene A. 1949. Morphology. 2nd ed. Ann Arbor: University of Michigan Press.

Pike, Kenneth L. 1947. Phonemics. A Technique for Reducing Languages to Writing. Ann Arbor: University of Michigan Press.

Puderbaugh, Rebekka. 2019. Laryngealization in Upper Necaxa Totonac. Ph.D. Dissertation, University of Alberta.

Reid, Aileen A. 1991. Gramática totonaca de Xicotepec de Juárez, Puebla. México: Instituto Lingüístico de Verano.

Reid, Aileen A., Ruth G. Bishop. 1974. Diccionarío totonaco de Xicotepec de Juárez, Puebla. Vocabularios y diccionarios indígenas "Mariano Silva y Aceves", vol. 17. México: Instituto Lingüístico de Verano.

Shosted, Ryan K., Sharon Rose. 2011. Affricating ejective fricatives: The case of Tigrinya. Journal of the International Phonetic Association 41(1): 41-65.

Tino, Jorge Antonio. 2020. Las vocales laringizadas y su manifestación fonética en el totonaco de Olintla. Lingüística Mexicana, Nueva Época 2(1): 7-30.

Trechsel, Frank R., Alice Faber. 1992. Acoustic properties of plain and laryngealized vowels in the Misantla dialect of Totonac. Ms. Universidad de las Américas, Puebla, México.

Troiani, Duna. 2004. Aperçu grammatical du totonaque de Huehuetla, Puebla, Mexico. Lincom: Munich.

Watters, James K. 2018. Sobre la relación histórica entre las vocales laringizadas y las eyectivas en totonacotepehua. In: Elsa Cristina Buenrostro, Lucero Meléndez Guadarrama, Marcela San Giacomo Trinidad (eds.). Lingüística histórica de lenguas indomexicanas: hallazgos y discusiones recientes: 125-138. IIA-UNAM: México. 
А. И. Давлетшин. Дарингализованные гласные и ларингализованные согласные в истории тотонакских языков Мексики.

В статье доказывается, что язык тотонако-де-папантла нейтрализовал праязыковое противопоставление между модальными и ларингализованными гласными после сонорных, в результате чего возникла система, основанная на противопоставлении простых и глоттализованных смычных, аффрикат и сибилянтов. Сходными образом в родственном тотонако-де-мисантла было утрачено противопоставление между модальными и ларингализованными гласными после сибилянтов, вместо которого развилась система глоттализованных смычных, аффрикат и сонорных. Оба звуковых перехода понятны с той точки зрения, что три класса согласных (смычные и аффрикаты, сонорные и сибилянты) артикуляторно подразумевают разные механизмы глоттализации. Известно, что глоттализованные сонорные встречаются в языках мира реже, чем глоттализованные смычные и аффрикаты, а глоттализованные сибилянты реже, чем глоттализованные сонорные. В свете полученных данных, тотонако-де-апапантилья и тотонако-де-сапотитлан-де-мендес оказываются консервативными языками подгруппы и, таким образом, имеют особую значимость для реконструкции пратотонакских ларингализованных гласных.

Ключевые слова: тепеуа-тотонакские языки; тотонакские языки; ларингализованные гласные; скрипучий голос; глоттализованные согласные; абруптивные согласные; ларингализованные согласные; глоттализованные сибилянты; глоттализованные сонорные. 